\title{
Epidemiological and molecular characterization of antigens extracted from Hydatid cysts of camel, cattle and donkeys in Egypt
}

\author{
O. A. Mahdy*, Abdel Maogood S. Z, Abdel Wahab A. M, M. M. El-Bahy \\ Department of Parasitology Faculty of Veterinary Medicine, Cairo Univ. El-Giza, Egypt \\ *Corresponding author E-mail: dr.olfat.mahdy@cu.edu.eg
}

Copyright $\odot 2014$ O.A. Mahdy et al. This is an open access article distributed under the Creative Commons Attribution License, which permits unrestricted use, distribution, and reproduction in any medium, provided the original work is properly cited.

\begin{abstract}
Cystic echinococcosis or Hydatid disease is recognized as an important worldwide distributed disease from the clinical, economical and zoonotic point of view. In the present work, 180 camels and 90 cattle freshly slaughtered at Cairo abattoir and 120 donkeys scarified at Giza zoo, were inspected for infection by Hydatid cysts (HC) in Egypt. The highest incidence of $\mathrm{HC}$ infection was $18.9 \%$ in Camel, $14.2 \%$ in donkeys and the lowest $3.3 \%$ in cattle. Regarding the site of $\mathrm{HC}$ infection was $94.3 \%$ and $90.2 \%$ in Camel lungs and donkeys liver. The fertility of $\mathrm{HC}$ was $79.24 \%$ and 29.4\% from camel and donkeys, while, all inspected hydatid cysts collected from cattle were found calcified. Germinal membranes of fertile HC were used for DNA extraction followed by PCR amplification. It was used for identification of internal transcribed spacer gene1(ITS1)from camel and donkeys by using specific primer. The amplified DNA fragment was further analyzed by PCR mediated restriction fragment length polymorphism (PCR $\neg$ RFLP) using two restriction enzymes (MSP1 and RSA1). The PCR yielded similar amplified DNA band of the same molecular size marker at 1115 bp in different isolates of Hydatid. No band variation of ITS 1 gene could be detected by PCR- RFLP by using two restriction enzymes. Amplification product of ITSI after digestion with MSP1 showed at $661 \mathrm{bp}$, while those restricted with RSA1 enzyme appeared at $745 \mathrm{bp}$.
\end{abstract}

Keywords: Molecular, Hydatid cyst, Antigens, PCR, Camel and Donkeys, Egypt.

\section{Introduction}

Cystic echinococcosis or hydatid disease is one of the most important worldwide distributed disease from the clinical, economical and zoonotic point of view causing sever animal and human health problem [1]. It is a helminthic cyclozoonosic disease caused by the larval stage (metacestode) of the canid tapeworm Echinococcosis that require at least one other vertebrate host for completion of its life cycle. The disease is endemic in many parts of the world [2]. It is one of the major zoonotic parasitic diseases in the Middle East and Arab North Africa from Morocco to Egypt [3]. The disease has great public health importance and economic impact in countries where livestock industry is an important segment of the agricultural sector and when livestock production is based mainly on extensive grazing system [4].

Concerning molecular characterization of E. granulosus, the parasite poses a high degree of genetic diversity based on genome pattern, morphology and host specificity have allowed the differentiation of at least Ten different genotypes (G1- G10) among which G4 (horse strain) have been formerly characterized [5] [8] and Camel strain (G6) have been formally in Eastern Africa [9] North Africa [10] and Tunisia [11].

The present study, was conducted on slaughtered camel, cattle and scarified donkeys aiming to determine the incidence rate of Hydatid cysts infection, the site of infection and fertility of cysts. PCR was used for amplification of DNA extracted from fertile HC for identification of ITS1 gene of camel and donkeys followed by further identification by PCR- RFLP using two digestive. 


\section{Material and methods}

This study was assessed and approved by Faculty of Veterinary Medicine, Cairo University Ethics Committee and therefore been performed in accordance with the ethical standards laid down in the 1964 Declaration of Helsinki.

\subsection{Collected samples}

HC were collected from freshly slaughter animals 270 (180 camels, 90 cattle) at Cairo abattoirs and from inspected 120 donkeys on post- at the zoo of Giza Zoo, Egypt. The donkeys were brought to the zoo for feeding lions. They were examined for the presence of $\mathrm{HC}$ on post- slaughtered and post- mortem inspection during the period from December 2011 to November 2012. Intact HC, isolated from the infected animals, were put separately in the polythene bags containing ice and brought to Veterinary Medicine of Cairo University for further processing. Examination of all internal organs was also done by using palpation and incision for the detection of $\mathrm{HC}$ according to the technique recommended by [12].

\subsection{Identification of $\mathrm{HC}$}

The suspected infected organs were collected from slaughtered and scarified animals for routine microscopic examination according to [13]. Cyst fluid was obtained from pulmonary and hepatic cysts for demonstration of protoscolices and hooklets. Protoscolices were isolated from the fertile cysts and then washed three times by phosphate buffer saline (PBS), pH 7.2 and preserved in $70 \%$ alcohol (v/v) for isolation of DNA [14].

\subsection{DNA extraction:}

DNA was extracted from germinal layer of fertile HC using Genei Ultrapure TM Mammalian Genomic DNA Purification Tissue Kit (Bangalore Genei). According to manufacturer's instructions, 25 $\mu$ l of the antigen were suspended in $500 \mu \mathrm{l}$ of $\mathrm{CTAB}$ buffer and transferred to a microfuge tube, incubated for $15 \mathrm{~min}$. at $55^{\circ} \mathrm{C}$ in water bath, then the mixture was centrifuged at $12000 \mathrm{rpm}$ for $5 \mathrm{~min}$. and the supernatant transferred to a clean microfuge tubes. To each tube 250ul of chloroform: IsoAmyl alcohol (24:1) was added and the solution then mixed by inversion. The mixture was spanned at $13000 \mathrm{rpm}$ for $1 \mathrm{~min}$. Here the upper aqueous phase contained the DNA which is transferred to a clean microfuge tube. To each tube $50 \mu \mathrm{l}$ of $7.5 \mathrm{M}$ Ammonium acetate was added followed by $500 \mu \mathrm{l}$ of ice cold absolute ethanol to precipitate the DNA. The precipitate was transferred into a microfuge tube containing $500 \mu 1$ of ice cold $70 \%$ ethanol and then centrifuged at $13000 \mathrm{rpm}$ for 1 minute supernatant discarded and the remaining DNA pellet washed by adding $70 \%$ ethanol, then centrifuged at $13000 \mathrm{rpm}$ for $1 \mathrm{~min}$. and again the supernatant removed and the DNA re-suspended in DNAse and incubated at $65^{\circ} \mathrm{C}$ for $20 \mathrm{~min}$ and stored at $4^{\circ} \mathrm{C}$.

\subsection{PCR Assay}

Amplification of ITS1 gene was done by using of primers described by [15]. The primer was designed as forward 5 GTC GTA ACA AGG TTT CCG TA'3 and reverse 5'TCT AGA TGC GTT CGA A (G/A) TGT CGA TG'3, (Jena, Bioscience, Germany). A100-bp DNA was used as molecular size marker. The amplification reaction was carried in $25 \mu \mathrm{l}$ volume containing 500mM Kcl, 10 mm Tris- Hcl (PH9.0), 1\% Triton x-100, 4 mm Mgcl, 100uM DNTPs each, 1520ng of ITS1 primer, 25ng of DNA and 1.5 units of Tag DNA polymerase. For data analysis PCR assay was performed in thermal cycler (Teche TC - 512UK). The DNA was denaturated for $6 \mathrm{~min}$. at $95^{\circ} \mathrm{C}$. The mixture was then subjected to 30 cycles of denaturation at $94^{\circ} \mathrm{C}$ for $45 \mathrm{sec}$., annealing of primers at $55^{\circ} \mathrm{C}$ for $60 \mathrm{sec}$. and primer extensions at $72^{\circ} \mathrm{C}$ for 90 second. The final extension was held at $72^{\circ} \mathrm{C}$ for $1 \mathrm{~min}$. PCR products were analyzed after electrophoresis in $1.5 \%(\mathrm{~W} / \mathrm{v})$ Agarose gel and visualized in Ethidium bromide.

\subsection{PCR mediated RFLP}

PCR product were digested with MSP1 and RSA1 (10u) using buffer recommended by the manufacture (Jena Bioscience, Germany). Restriction fragments were separated by gel electrophoresis through 2\%TBE Agarose gel. PCR products were analyzed after electrophoresis in $1.5 \%(\mathrm{~W} / \mathrm{v})$ Agarose gel and visualized in Ethidium bromide.

\section{Results}

The data demonstrated in table (1) cleared that the total incidence of infection by HC was $18.9 \%, 3.3 \%$ and $14.2 \%$ among examined camels, cattle and donkeys respectively. The cyst was diagnosed in $5.7 \%, 66.7 \%$ and $90.2 \%$ of the examined liver respectively, while, it was $94.3 \%, 33.3 \%$ and $9.8 \%$ in the examined lung of camels, cattle and donkeys 
respectively, table (2). Moreover, the rate of fertile cysts was found to be $42(79.24 \%)$ in camel and $15(29.4 \%)$ in donkeys. while, all cysts collected from the inspected cattle were found calcified. table (3).

Microscopically, the higher incidence of viable motile protoscoleces $(60.4 \%)$ was found in HC of camel origin, then $(23.5 \%)$ in HC of donkey origin. The highest incidence of non-motile protoscoleces (18.9\%) was found in that of camel origin while it was $5.9 \%$ in that of donkey origin, table (4).

Table 1: Incidence of HC Infection in Examined Animals.

\begin{tabular}{llllll} 
& \multicolumn{5}{c}{ Table 1: Incidence of HC Infection in Examined Animals. } \\
\hline Animals & No. Ex. & No. Inf. & $\%$ & No. cysts & Mean and average No. Cyst/ animals \\
\hline Camels & 180 & 34 & 18.9 & 53 & $(1-3) 1.55$ \\
Cattle & 90 & 3 & 3.3 & 6 & $(1-2) 1$ \\
Donkeys & 120 & 17 & 14.2 & 51 & $(2-3) 3$ \\
Total & 390 & 54 & 13.8 & 110 & \\
\hline
\end{tabular}

Table 2: Incidence of HC Distributions in Different Site of Infection in the Examined Animals

\begin{tabular}{|c|c|c|c|c|c|}
\hline \multirow[t]{3}{*}{ Infected animals } & \multirow[t]{3}{*}{ No. cysts } & \multicolumn{4}{|c|}{ Site of infection } \\
\hline & & \multicolumn{2}{|c|}{ Lung } & \multicolumn{2}{|c|}{ Liver } \\
\hline & & No. & $\%$ & No. & $\%$ \\
\hline Camels & 53 & 50 & 94.3 & 3 & 5.7 \\
\hline Cattle & 6 & 2 & 33.3 & 4 & 66.7 \\
\hline Donkeys & 51 & 5 & 9.8 & 46 & 90.2 \\
\hline Total & 110 & 57 & 51.8 & 53 & 48.2 \\
\hline
\end{tabular}

Table 3: Incidence of Sterile and Fertile HC in the Examined Animals.

\begin{tabular}{|c|c|c|c|c|c|c|c|c|c|c|}
\hline \multirow{2}{*}{ Animals } & \multirow{2}{*}{$\begin{array}{l}\text { No. } \\
\text { Ex. }\end{array}$} & \multirow{2}{*}{ No Inf. } & \multirow[t]{2}{*}{$\%$} & \multirow{2}{*}{$\begin{array}{l}\text { No. } \\
\text { Cyst }\end{array}$} & \multicolumn{2}{|c|}{ Sterile HC } & \multicolumn{2}{|c|}{ Fertile HC } & \multicolumn{2}{|c|}{ Calcified HC } \\
\hline & & & & & No & $\%$ & No. & $\%$ & No. & $\%$ \\
\hline Camels & 180 & 34 & 18.9 & 53 & 3 & 5.7 & 42 & 79.24 & 8 & 15.1 \\
\hline Cattle & 90 & 3 & 3.3 & 6 & 0 & 0 & 0 & 0 & 6 & 100 \\
\hline Donkey & 120 & 17 & 14.2 & 51 & 17 & 33.3 & 15 & 29.4 & 19 & 37.3 \\
\hline Total & 390 & 54 & 13.8 & 110 & 20 & 18.2 & 57 & 51.8 & 33 & 30.0 \\
\hline
\end{tabular}

Table 4: Incidence of HC According to Viability of Protoscoleces

\begin{tabular}{|c|c|c|c|c|c|c|}
\hline \multirow{3}{*}{ Animals } & \multirow{3}{*}{ No.Cyst } & \multirow{3}{*}{$\begin{array}{c}\text { No. fertile cyst } \\
\text { No. }\end{array}$} & \multicolumn{4}{|c|}{ Fertile cysts with } \\
\hline & & & \multicolumn{2}{|c|}{ Motile Protoscoleces } & \multicolumn{2}{|c|}{ Non-motile Protoscoleces } \\
\hline & & & No. & $\%$ & No. & $\%$ \\
\hline Camels & 53 & 42 & 32 & 60.4 & 10 & 18.9 \\
\hline Cattle & 6 & 0 & 0 & 0 & 0 & 0 \\
\hline Donkeys & 51 & 15 & 12 & 23.5 & 3 & 5.9 \\
\hline Total & 110 & 57 & 44 & 40 & 13 & 11.9 \\
\hline
\end{tabular}

The genetic characters of HC obtained from camel and donkeys after PCR amplification of ITS1 gene showed similar pattern of PCR product, all amplified DNA products have band of the same molecular size at 1115bp on Agarose gel (Fig.1).

Furthermore, molecular analysis using PCR-RFLP for amplification to the product of ITS1 after digestion with MSP1 showed that all strains sharing in the MW at 661 bp (Fig.2A), while those restricted with RSA1 enzyme appeared at 745 bp ((Fig.2B).

\section{Discussion}

Hydatid cyst (HC) the larval stage of the dwarfed tape worm of dogs, Echinococcus granulosus, develops in the internal organs of human and herbivore intermediate hosts, mainly in the liver and lung [16]. In Egypt the prevalence of hydatidosis still a point under investigation, In the present study, the incidence of HC were $18.9 \%$ and $3.3 \%$ in slaughtered camels and cattle from Cairo abattoirs. This result was in agreement with [17-18] who recorded $18.9 \%$ \& $17.61 \%$ in slaughtered camels in Ismailia and Cairo abattoirs, Egypt. In the same time, this result considered to be lower than that recorded by [19] in Assiut governorate, as 7.67\% in camels and no infection was recorded in the examined cattle and buffaloes. Presently, incidence of donkey HC infection was (14.2\%) this finding considered to be higher than that result by [20]. On the other hands, the low incidence of Cattle HC infection (3.3\%) was in agreement with [21] \& [19] where, both of them failed to diagnose HC infection in the examined slaughtered cattle.

According to the present study, the rate of infection in camel was higher in Lung (94.3\%) than in liver (5.7\%). An observation in accordance with that noticed in Egypt camel, [18], [22] who found that 100\%, 63.7\%. And 94.6\% in lung camel. 
In the present study, the majority of infected donkeys $(90.2 \%)$ harbored $\mathrm{HC}$ in their liver. This result was in agreement with [8], who revealed that the majority of infected donkeys (70\%) in their livers at Beni-Suef, Egypt.

From the epidemiological and molecular aspects, fertility of $\mathrm{HC}$ is one of the most important factors in the epidemiology of E. granulosus. The fertility of cyst varies depending on the hosts and geographical situations [23]. In the current study, fertility rate of HC in camel and donkeys have been found to be $42(79.24 \%)$ in camel lung and 15 $(29.4 \%)$ in donkey liver. The high rate of fertile cyst may indicate that the cause of infection in investigated animals might be due to camel and donkeys strain (G6 \& G4). As such genotype is commonly recognized as a predominating species of E. granulosus in Mediterranean countries [24].

In the present work, molecular genetics study has been carried out to identify the genetic characters of HC obtained from the infected camel and donkeys. After PCR amplification of ITS1 gene, similar amplified DNA band of the same molecular size marker at $1115 \mathrm{bp}$ were recorded in the different isolates. No band variation of ITS 1 gene could be detected by PCR-RFLP after using the two restriction enzymes, MSP1 and RSA1, This meaning absence of ITS1 variant which could not differentiated using these two restriction enzymes. This was in agreement with [25-26]. In the author's opinion and in agreement with [26] absence of variation in amplified ITS1 and indistinguishable genetic character in PCR-RFLP, meaning that the analyzed camel and donkey HC samples are infected with E. granulosus of sheep strain. This can be accepted as all examined animals are from the same localities. Moreover more research are continue aiming to further identification of Hydatid infection of camel and donkeys based on PCR amplification and sequence of mitochondrial genes.

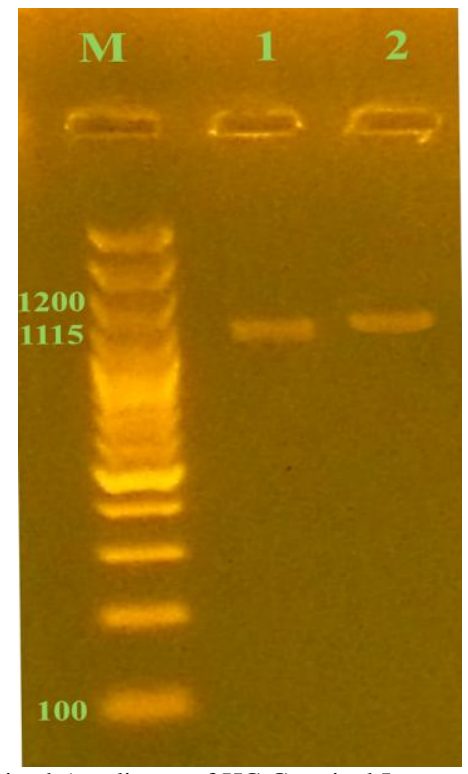

Fig. 1: Agarose Gel Electrophoresis of The PCR-Derived Amplicons of HC Germinal Layer of E. granulosus ITS1 Gene, Separated on 2\% Agarose Gel and Stained With Ethidium Bromide Lanes: (M) 100 Bp DNA Ladder (Consists of Repeats of 100 Bp Fragment Size, Fermintas), Lane 1Camel DNA \& 2 Donkey DNA Containing 1115 Bp.

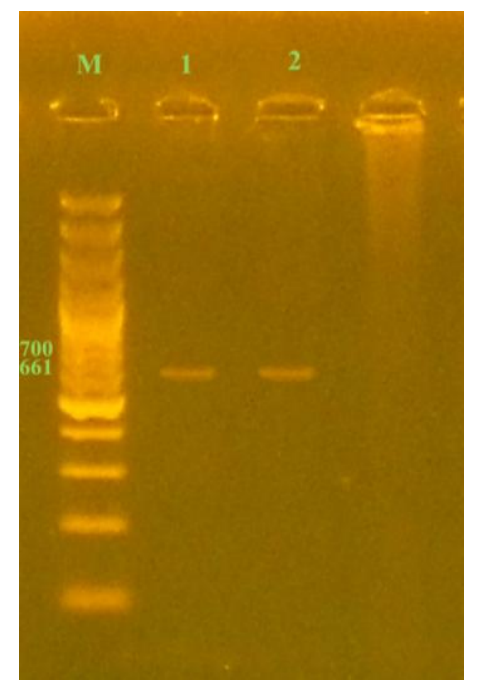

Fig. 2 (A): Agarose Gel Electrophoresis of the PCR-Derived Amplicons of HC Germinal Layer of E. granulosus ITS1 Gene After Digestion with MSP1 Separated on 2\% Agarose Gel and Stained With Ethidium Bromide Lanes: (M)100 Bp DNA Ladder(Consists of Repeats of 100 Bp Fragment Size, Fermintas), Lane 1Camel DNA \& 2 Donkey DNA Containing 661 Bp. 


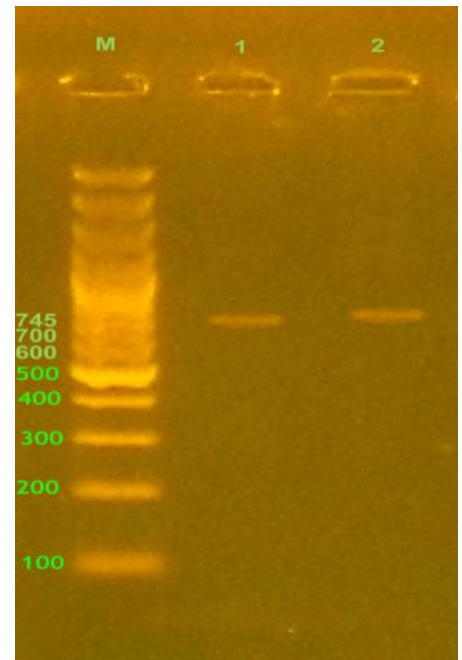

Fig. 2 (B): Agarose Gel Electrophoresis of the PCR-Derived Amplicons of HC Germinal Layer of E. granulosus ITS1 Gene After Digestion with RSP1 Separated on 2\% Agarose Gel and Stained With Ethidium Bromide Lanes: (M) 100 Bp DNA Ladder (Consists of Repeats of 100 Bp Fragment Size, Fermintas), Lane 1Camel DNA \& 2 Donkey DNA Containing 745 Bp.

\section{Acknowledgment}

The authors acknowledge Cairo Univ. vice President of postgraduates and research for funding this project. Deep acknowledges for veterinarians and workers of Cairo slaughter houses as well as the staff of Giza zoo for their appreciable help and their permission for the authors to examine the carcass of slaughtered donkeys in the zoo.

\section{References}

[1] Lightowlers M. W., Flisser A., Gausi C.G., Heath D.D. Jensen O. and Rolfe R. (2000): Vaccination against cysticercosis and hydatid disease. Parasitology Today, 16: 191-196.

[2] Willingham A .L. (2003): New research opportunities in meat -borne and other parasitic zoonoses. WHO/FAO collaborating center for research and training on Emerging and other parasitic zoonoses, Denmark. Pp. 21.

[3] Sadjjadi S. M. (2006): Present situation of echinococcosis in Middle East and Arabic North Africa. Parasitology international, 55: 197-202.

[4] Gebretsadik B. (2009): Abattoir survey on cattle hydatidosis in tigray region of Ethiopia. Tropical Animal Health and Production, 41(7): 13471352 .

[5] McManus D.P., (2002): The molecular epidemiology of E. granulosus and cystic hydatid disease. Trans. R. Soc. Trop. Med. Hyg. 96 (1), S151-S157.

[6] Lavikainen A., Lehtinen M. J., Meri T., Hirvela-Koski V., Meri, S.,(2003): Molecular genetic characterization of the Fennoscandian cervid strain, a new genotypic group (G10) of E. granulosus. Parasitology 127 (3), 207-215.

[7] Snabel V, Altintas N., D’Amelio S., Nakao M., Romig T., Yolasigmaz A., Gunes K., Turk M., Busi M., Hüttner M., Sevcova D., Ito A., Altintas N., Dubinsky P., (2009): Cystic echinococcosis in Turkey: genetic variability and first record of the pig strain (G7) in the country. Parasitol. Res. 105.

[8] Aboelhadida S. M., K. M. El-Dakhlya, Tokuma Y., H. Fukushi and K. M. Hassanin (2013): Molecular characterization of E. granulosus in Egyptian donkeys Veterinary Parasitology 193; 292- 296.

[9] Dinkel A., Njoroge E., Zimmermann A., Walz M., Zeyhle E., Elmahdi I., Mackenstedt U., Romig T. (2004): A PCR system for detection of species and genotypes of E.granulosus complex, with reference to the epidemiological situation in eastern Africa. Int. Parasitol. 34: 645-653.

[10] Bart J. M., Bardonnet K., Elfegoun M.C. B., Dumon H. Dia L. Vuitton D.A. Piarroux R. (2004): E.granulosus strain typing in North Africa: Comparison of eight nuclear and mitochondrial DNA fragments. Parasitol. 128: 229-234.

[11] M'rad S., Filisettib, D., Oudnia, M., Mekkic, M., Belguithc, M., Nouric, A., Sayadid, T., Lahmare, S., Candolfib, E., Azaieza, R., Mezhouda, H., Babbaa, H. (2005): Molecular evidence of ovine (G1) and camel (G6) strains of E. granulosus in Tunisia and putative role of cattle in human contamination. Vet. Parasitol.129: 267-272.

[12] Gracy J. F. (1986): Thornton's Meat Hygiene. Bailliere Tindall, London, 7th Ed.

[13] Heath D., Li H. and Donald P. (2005): Short report in adequacy of yaks as hosts for the sheep dog strain of E. granulosus or for E. multilocularis. Am. J. Trop. Med. Hyg. 72: 289-290.

[14] WHO/OIE (2001): Manual on Echinococcosis in Human and Animals: Public Health Problem of Global Concern. World Organization for Animal Health, Paris, France. pp 17-19.

[15] Bowles J. and McManus D.P. (1993): NADH dehydrogenase 1 gene sequences compared for species and strains of the genus Echinococcus. Int. J. Parasitol. 23 (7), 969-972.

[16] Rostami Nejad, M., Hoseinkhan, N., Nazemalhosseini, K., Abdinia, E., Zali, M.R. (2007): An analysis of hydatid cyst surgery in patients referred to hospitals in Khorram Abd, Lorestan during 2002-2006. Int. J. Parasitol. 3: 29-33.

[17] Abou-Eisha A. M. (1999): Prevalence of hydatid cysts in slaughtered animals in relation to public health. Proceedings of the fifth scientific Congress Egyptian Society for cattle diseases, Assuit, Egypt, p. 231-237.

[18] El-Kattan A.M.A.E.M. (2012): Some studies on Hydatidosis in Camels Ph.D.V.Sc. Thesis Infectious Diseases. Fac. Vet. Med. Cairo University, Egypt.

[19] Dyab K. A., Hassanein R., Hussein, A. A., Metwally S. E. and Gaad H. M. (2005): Hydatidosis among man and animals in Assuit and Aswan governorates, J. Egypt. Sco. Parasitol., 35(1): 157-166.

[20] Haridy F., M. Holw S. A., Hassan A. A. and Morsy T.A. (2008): Cystic hydatidosis: a zoonotic silent health problem J. Egypt Soc. Parasitol. 38(2):635-44. 
[21] Haridy F. M., Ibrahim B. B., Elshazly A. M. Awad S. E., Sultan D. M., El-Sherbini G.T., Morsy T. A. (2006); Hydatidosis granulosus in Egyptian slaughtered animals in the years 2000-2005. J Egypt Soc. Parasitol; 36: 1087-1100.

[22] Salih M., Hailu D. and Moti Yohannes M. (2011): Infection Rates, Cyst Fertility and Larval Viability of Hydatid Disease in Camels (Camelus dromedarius) from Borena, Kereyu and Harar Areas of Ethiopia. Global Veterinaria, 7 (6): 518-522.

[23] Komenetzky 1., Canova S., Guemera E., Rosenvit M. (2000): DNA extraction from germinal layers allows strain determination in fertile and nonfertile hydatid cysts. Exp. Parasitol. 95: 122-127.

[24] Jenkins D., Romig T., and Thompson R. (2005): Emergence / re-emergence of Echinococcus spp-aglobal update. Int. J. Parasitol. 35: 12051219.

[25] Bhattacharya, D., Bera, A.K., Bera, B.C., Pan, D., Das, S.K. (2008): Molecular appraisal of Indian animal isolates of Echinococcus granulosus. Indian J. Med. Res. 127:383-387.

[26] El- Madawy Reham S., Nashwa O. Khalifa, Jehan, S.A. Afify (2011): Epidemiological And Molecular Studies of Hydatid cyst In Slaughtered Cattle And Sheep In Toukh, Egypt, Benha Veterinary Medical Journal, special issue [I]: 95-101. 